which I was able to apply it the presence of fluid might have been determined beyond reasonable doubt. When properly checked by test and counter-test the paravertebral triangle is our finest and apparently our only reliable reagent for the detection of small amounts of free fluid at the base of the pleura and also for some estimate as to its quantity. This method of diagnosis is at the same time by far the easiest and the most rapid to carry out. It is, therefore, likely to be regarded in the future not only as important but as often indispensable. I am, Sirs, yours faithfully, William Eivart.

Ourzon-street, Mayfair, W., July 14th, 1907.

\section{THE TSETSE FLY.}

To the Editors of THE LANOET.

SIRs,-At a time when so much interest is being taken in the tsetse fly it may be of interest to some of your readers to make known publicly what I have already mentioned to one or two medical friends. About three years ago (when I was travelling commissioner here) I asked some native chiefs if they $\mathrm{knew}$ the $\mathrm{fly}$ that did harm to their cattle. They said they did but that the fly did no damage unless it had previously bitten a "red" monkey. By this I think is meant a "yellow" monker, not uncommon out here (the natives have no names for different shades of colour as we have), and I never saw a " red" monkey. I give this for what it is worth, but there was no reason why a monkey should have been mentioned any more than a goat unless the natives thought there was some truth in the statement. Westwood ("Introduction to Study of Insects") mention in a footnote that $M$. Vallot noticed the existence of an cestrideous larva in a monkey, and possibly it was a zimb. The matter seems worth looking into at any rate.

I am, Sirs, yours faithfully,

J. WINN SAMPSON, F.R.M.S.,

Calabar, South Nigeria, June 14th, 1907. Police Magistrate.

\section{THE HAMPSTEAD GENERAL HOSPITAL. To the Editors of THE LANOET.}

SIRS,-In your last issue Mr. A. Craske makes a great deal of what is obviously an error in the report of my speech. My assertion was that the income from the invested funds of the North.West London Hospital was under $£ 200$ a year; it is actually $£ 170$.

I am, Sirs, yours faithfully.

E. Corlingwood ANDrews.

Hampstead, N.W., July 16th, 1907.

\section{THE IMAGINATIVE TEMPER IN SCIENCE} To the Editors of THE LANCET.

SIRs,-I think homœopaths will have good reason to grumble with your article on the "Imaginative Temper in Science" and to comment on the taste and tact of the writer and also of the Editor in introducing this subject into a leading article and making statements about it which its followers will be unable to controvert, not because the cannot, but because their replies would be boycotted, as this one will be, by the Editor who places as a motto over one of his columns "Audi alteram partem."

I am, Sirs, your obedient servant,

Dewsbury, July 14th, 1907. J. J. G. PRITCHARD.

\section{A NIGHT SHELTER FOR WOMEN AND GIRLS.}

To the Editors of THE LANCET.

SrRs, - We beg your courtesy for a little space in your valuable journal for a special appeal on behalf of a cheap and decent night shelter for women and girls which we are anxious to establish in London. The idea is the outcome of hundreds of sympathetic letters received since the publication of "The Soul Market" which gave Mrs. Archibald MacKirdy's personal experiences among the poor and outcast. A lady has promised us $£ 1000$ if four other ladies or gentlemen will give or collect like sums.

The plans for the shelter are made on the most economical and practical lines. It is hoped it will, when built and equipped, be self-supporting. The charges will be $2 d$. to $4 d$. a night and this refuge will be the means of helping many a girl and woman back to good citizenship and decent living. We are favoured with Royal sympathy and our committee include the following ladies and gentlemen among others :The Duchess of St. Albans, Lady Wemyss, Lady Brassey, Lady Rvelyn Moreton, Lady Wright, Mrs. Herbert Gladstone, Lord Reay, Lord Curzon, Lord Brassey, Lord Stratbcona, Sir W. Wright, Sir Dyce Duckworth, Sir W. S. Gilbert, and the Rэv. Arch. Fleming.

Subscriptions may be sent to Lady Brassey, the treasurer of the fund, at, 24, Park-lane, London, W.

We are, Sirs, yours very truly,

SYIBI DE V. BRASSEY,

July 12th, 1907.

Olive Christian MacKirdy.

\section{THE REFORM OF THE ROYAL NAVY MEDICAL SERVICE.}

To the Editors of THE LANCET.

Sirs, - The Lords Commissioners of the Admiralty have just issued an order that naval medical officers are not to receive fees for evidence at coroner's inquests or for performing post-mortem examinations on a coroner's order, and that they are to consider this part of their duty as naval medical officers. I ask you to publish this letter because I think that this order may have been issued before their lordships had been sufficiently well advised upon the matter, and also in order that we may hear through your valuable columns the opinions of some of our brothers in the profession. I have always believed that on taking our diplomas to practise as medical men and becoming registered we were, partiy by power of the Charter of the Medical Faculty to which we belonged and partly by right as a registered medical practitioner, entitled to certain privileges and at the same time bound by certain restrictions. The right to demand fees from a coroner I have always looked on as a right conferred by being a registered medical man. Surely, if one class of Government officials are to be debarred from receiving these fees that can only be done by Act of Parliament, which would alter the coroner's law, and at the same time surely it should be made applicable to all paid out of the public purse, whether Admiralty, War Office, Local Government Board, or municipal authority.

I regret to say that there is a feeling of uncertainty in our branch of the profession as to whether you would care to ventilate our grievances in your valuable journal owing to pressure from the medical department of the Admiralty, who are not anxious that candidates for the Service should be deterred from joining when they read what is published. As I am sure that you would not close your valuable journal to any true and sensible grievance I send you this letter. There is a widespread view, that it is quite time that the suggested reforms by which many were lately induced to enter the Service should be brought in as there is a great desire for improvement by many, not in the direction of pay, rank, or privileges, but in promotion of efficiency throughout the Service. The open disapproval shown to men who endeavour to improve their general knowledge by working at bacteriology has caused much discontent. The present way of distributing hospital appointments which are so few as to be insufficient to enable every medical officer to obtain one during his whole career in the Service and which could so easily be remedied by shortening the term of office; and in order to avoid long journeys and expense to the department in travelling exchanges could be effected every 12 months with men serving in the port or in the fleet attached to the station. The present system of employment of large numbers of medical officers in the home and reserve fleets which all have reduced crews and most of the home fleet ships having two medical officers. These fleets, the home and reserve, have not sufficient work for one man for three ships. It certainly shows the kindness and generosity of the Admiralty in keeping the officers on full pay, but I for one would much rather have efficiency than idleness, as once appointed to one of these ships one has to remain on board daily from 9 A.M. to 1.30 and most ships until 3.30 , although there may not be one man sick and there is always one ship flying a medical guard flag which signifies an officer on board all day for emergency. There are many who suggest that in the case of these medical officers they should, after visiting their ship in order to see the sick, be appointed to the hospital as medical or surgical registrars in order to keep 